\title{
Survival response of Sarotheron melanotheron (Ruppel, 1852) fingerlings to various concentration levels of perfkthion under laboratory condition
}

\author{
IROEGBU, B C ${ }^{1}$; HART, A I ${ }^{1}$; ABOWEI, J F N
}

\author{
${ }^{1}$ Department of Animal and environmental biology, University of Port Harcourt Rivers State. ${ }^{2}$ Department of Biological Sciences,
} Niger Delta University, Bayelsa State.

\begin{abstract}
Survival response of Sarotheron melanotheron fingerlings to various concentration levels of perfkthion was studied under laboratory condition using five concentration levels, $0.0 \mathrm{mg} / 1,0.7 \mathrm{mg} / 1,1.4 \mathrm{mg} / \mathrm{l}$, $2.8 \mathrm{mg} / 1,5.5 \mathrm{mg} / 1$ and $11.2 \mathrm{mg} / \mathrm{l}$. Mortality increased with increase in concentration level and exposure time. Ten percent mortality was observed in the control $(0 \mathrm{mg} / 1), 3 \%$ mortality was recorded after 12 hours and $7 \%$ at the end of 36 hours. At the lowest concentration of $0.7 \mathrm{mg} / 1,27 \%$ mortality occurred after 12 hours and $30 \%$ mortality occurred after 24 hours. At the 48th hour, the rate increased to $37 \%, 47 \%$ after 72 hours and afterwards no further death was observed till the end of the experiment. At $1.4 \mathrm{mg} / 1,20 \%$ mortality occurred after 12 hours, this increased to $37 \%$ after 24 hours, $43 \%$ after 36 hours, $53 \%$ after 60 hours, $63 \%$ after 72 hours, $73 \%$ after 84 and $77 \%$ after 96 hours. Mortalities occurred in concentration level $2.8 \mathrm{mg} / 1$ at the rate of $7 \%$ after 12 hours, $13 \%$ after 24 hours, $20 \%$ after 36 hours and $7 \%$ mortality after 48 hours. This increased to $43 \%$ after 60 hours and remained at $47 \%$ mortality from the $72^{\text {nd }}$ hour till the end of experiment. At concentration level $5.6 \mathrm{mg} / \mathrm{l}$, mortality was $43 \%$ within 12 hours, this increased to $47 \%$ after 24 hours and $50 \%$ at the end of the $36^{\text {th }}$ hour. No further mortality occurred till the $60^{\text {th }}$ hour when $60 \%$ was observed. This continued to $63 \%$ after 84 hours and $67 \%$ at the end of the toxicity test. At concentration level $11.2 \mathrm{mg} / \mathrm{l}$, mortality was $43 \%$ at the $12^{\text {th }}$ hour. It increased to $70 \%$ at the $48^{\text {th }}$ hour and $97 \%$ at the 96 hour. There was significant effect of perfekthion on S. melanotheron fingerlings. There was delayed mortality at concentration $2.8 \mathrm{mg} / 1 . \mathrm{LC}_{50}$ was not reached within 12 hours. As exposure time increased, $\mathrm{LC}_{50}$ reduced. The median Lethal Time $\left(\mathrm{LT}_{50}\right)$ values for concentration levels, $1.4 \mathrm{mg} / 1,2.8 \mathrm{mg} / 1,5.6 \mathrm{mg} / 1$ and $11.2 \mathrm{mg} / 1$ was 57.85 hours, 91.52 hours, 48.35 hours and 27.61 hours respectively. $\mathrm{LT}_{50}$ increased with decrease in concentration level with the least value (27.61) at the highest concentration of $11.2 \mathrm{mg} / \mathrm{l}$ as compared to 57.85 hours at $1.4 \mathrm{mg} / \mathrm{l}$. The safe concentration of perfekthion organophosphate insecticide was $0.119 \mathrm{mg} / 1$. There were strong positive correlations between concentrations $(r=0.9982-r=0.9999)$. The correlation of $\mathrm{pH}$ with total alkalinity was $r=0.9379$, total hardness with salinity $(r=0.6705)$. Weak positive correlations occurred for $\mathrm{pH}$ and temperature $(\mathrm{r}=0.3516)$, temperature and $\mathrm{TA}(\mathrm{r}=0.2572)$ and; temperature and $\mathrm{TH}(\mathrm{r}=0.0419)$. Negative correlations occurred for $\mathrm{pH}$ and $\mathrm{DO}(\mathrm{r}=0.0604), \mathrm{pH}$ and $\mathrm{TH}(\mathrm{r}=-0.7524), \mathrm{pH}$ and salinity $(\mathrm{r}=$ $0.6369)$ and Do with salinity $(r=-0.1759)$. Strong positive correlation existed between mortality and $\mathrm{TH}(\mathrm{r}=$ $0.7795)$ and between mortality and salinity $(\mathrm{r}=0.8062)$. Negative correlation existed between mortality and $\mathrm{pH}$, TA $(r=-0.7681, r=-0.7977)$ and in mortality with DO and temperature $(r=-0.4479$ and $r=-0.2288)$. $@$ JASEM
\end{abstract}

Fishery resources are important sources of dietary proteins in most coastal communities in Nigeria and the world at large. This may the reason human populations have settled close to natural waters which; offer man's greatest hope for food and material supplies. However owing to efforts towards speedy industrialization, these natural waterways are being degraded. One industry, which contributes greatly to aquatic environment degradation and polluton is the pesticide industry. Pesticides reach the aquatic environment in a variety of ways: runoffs or drainage from treated agricultural lands. Although the amounts from this source may occasionally be large, many researchers have reported seasonal increases in residues that, coincides with peak periods. Rainwater can also be contaminated from direct applications to control pests such as mosquitoes and accidentally from large-scale forest or crop spraying. Such applications are seasonal and contaminate the water for only short period (Hanzota and Kasai, 1995)

Many industries use insecticides in their processes and the effluents from such factories contain large amounts of organo chloride insecticides such as deldrin, which are used in large quantities for moth-proofing by wood makers and carpet manufacturers. They are used by dry cleaners.
Some still escape into the aquatic environment. Atmospheric fallouts have been reported to be the major source of pesticide in the sea. Other sources of pesticides into the ocean include sewage effluent, which contain as much as $300 \mathrm{ppm} \mathrm{x}$ $10^{6} \mu \mathrm{g} / \mathrm{l}$ of dieldrin and $10^{6} \mu \mathrm{g} / \mathrm{l}$ of DDT and drainage from inefficient soak away pits (Hanzota and Kasai, 1995). Perkthion, as an organophosphate is characterized by acute exposure and is biologically active for only a few days. The effect is observed as acute poisoning when introduced at high concentration levels. As a member of carbamate family, it contains a substituted carbamic acid unit in each molecule. Its systemic action is seen as they are Tran located from the point of contact and are activated before reaching their site of action in insects (Hassal, 1990). Therefore, they are used against a wide range of phytophagous insects including aphids, bugs, leaf miners, thrips, white flies of ornamental plants and in farm animal hygiene in the control of flies (EXTONET, 1996). Its mode of action is AchE inhibition resulting to nerve exhaustion and nervous system failure while the respiratory muscle is the most critical muscle group affected leading to respiratory paralysis and ultimately to death. 
Sarotheron melanotheron belongs to the family Cichlidae. Its common name is black tilapia. It is primarily estuarine, but extends to fresh and salt waters, tolerating high salinities but sensitive to temperature and very fragile. They are primarily detritivores, feeding on alga, phytoplankton and aquatic vegetation and can grow and reproduced within a $\mathrm{pH}$ range of 3.5-5.2. S. melanotheron is a species of Africa, from Senegal to Zaire(Trewavas, 1983). and is differented from other tilapine species by black patch jaw or chins, slightly emerginate caudal fin and pale blue body colouration on its lower flank and becoming orange or metallic golden yellow at times with black patches (Cambell, 1987; Lee et al 1980). Toxicity work on S. melanotheron, are rare (Davids, 1999). Most research on the species was on feeding and growth. (Ufodike and Madu, 1986; Ufodike and Wada, 1991). Survival of $S$. melanotheron fingerlings exposed to various concentration levels of perfekthion organophosphate insecticide is needed to add to knowledge of their feeding, growth and response to pollutants to establish tolerance limit for perfekthion organophosphate insecticide in brackish water bodies for management decisions in similar water bodies.

\section{MATERIALS AND METHODS}

Perfekthion, an organophosphate insecticide was used for the experiment. It was obtained from Bertram and company limited, Port Harcourt. Perfekthion is a product of BASF chemical company Germany with ${ }^{\circledR}$ as their registered trademark and marketed by C. Zard Company limited, Lagos. It is mostly marketed as Dimethoate $(400 \mathrm{~g} / \mathrm{l})$, which is the common name and the active agent. It also contains cyclohexanone and xylene. Apart from Perfekthion, dimethoate has other trade names such as Rogor, Trimetion, Rogodan, Cygon 400 and Dimethoat Tech 95\%. Dimethoate belongs to the Dithiophosphates Phosphorothionate main group with the IUPAC name 0, 0-dimethyl Smethyl-carbomyl-methylphosphorodithioate. $S$. melanotheron fingerlings were collected from the African Regional Centre(ALUU Centre) Port Harcourt. Fresh apparently healthy fingerlings were collected with a scoop net of mesh size of $3.5 \mathrm{~mm}$. The fish was identified using monographs, descriptions, checklist and keys (Whitehead,1984; Gouerene and Teugel,1991; Loveque et. al, 1990). $S$. melanotheron fingerlings were transported from the field in aerated natural fresh water and held in the laboratory in $15 \%$ and $28^{\circ} \mathrm{c}$ charcoal- filtered, artificial brackish water. The fish were fed with feed obtained from ARAC at 3\% of their body weight. The fingerlings were two weeks old and were acclimatized to these conditions for seven (7) days before testing. Prior to the actual bioassay, the test organisms were subjected to five widely spaced concentrations and a control for 24 hours using the static bioassay method. The concentration with the highest survival was used for the serial dilution (FAO, 1973). In testing for tolerance to perfekthion organophosphate insecticide, a serial of dilution was made with brackish water of $0.25 \%{ }_{0}$ salinity. Concentrations were assessed following methods of Foster et. al, 1971 and Anderson et. al, 1974. Perfekthion insecticide $(2.5 \mathrm{ml})$ was collected and diluted to $1000 \mathrm{ml}$ with distilled water. Five concentrations of $0.7 \mathrm{mg} / \mathrm{L}, 1.4 \mathrm{mg} / \mathrm{L}, 2.8 \mathrm{mg} / \mathrm{L}$, $5.6 \mathrm{mg} / \mathrm{L}$ and $11.2 \mathrm{mg} / \mathrm{L}$ were obtained and used. In preparing a concentration of $0.7 \mathrm{mg} / \mathrm{L}, 0.7 \mathrm{ml}$ of the stock solution was taken with a pipette and made up to $1000 \mathrm{ml}$ (1 litre) of water. The final volume needed in each test chamber was obtained using the formula:

$$
\mathrm{C}_{1} \mathrm{~V}_{1}=\mathrm{C}_{2} \mathrm{~V}_{2}
$$

Where, $\mathrm{C}_{1}=$ concentration of stock solution (1000mg), $V_{1}=$ volume of stock solution needed for each concentration $; \mathrm{C}_{2}=$ desired concentration of test solution; $\mathrm{V}_{2}$ = final volume of water needed in test chamber (e.g. 10 liters) (EIFAC, 1983). This was repeated to obtain other concentration levels. Eighteen 10-litre glass aquaria were used for the test fish. Ten experimental fish were introduced into each of the test aquaria. Twenty- four hours prior to the experiment, feeding was stopped and fish was starved through out toxicity test. The bioassays were conducted at room temperature of $28^{0} \mathrm{c}$. The specimens were monitored initially at 15mims, 30mins, 1hour, 2hours, 4hours, 6hours, and 8hours. A 12 hourly monitoring was effected for mortality until the end of experiment. The renewal bioassays were carried out in the laboratory following the methods of Sprague, 1970; APHA, 1989 and FAO, 1973.

In the survival experiment, fingerlings were separately exposed for 24 hours at the end of which, the fish were retrieved, washed free of pollutants and reintroduced into pollutant free water. They were observed for another 24-hour recovery period. This process was done fore 120 hours for each treatment. The test fish were considered dead when, they laid suspended in test media ventral side upwards and failed to move at gentle prodding with a rod. No gill opercula movement observed, finally confirmed dead. Dead fish were removed immediately from test solution. From the mortality results, survival rate was extrapolated for each set of bioassay and was analyzed using methods of Litchfield and Wilcox, 1949. A $10 \%$ mortality was corrected using the formula: Corrected mortality $(\%)=$ $\underline{100}$ Observed mortality - Control mortality X

$$
100 \text { - Control mortality }
$$

The corrected mortality was used in place of calculated percent mortality.

Data obtained were presented as means plus or minus the standard deviation of the means (SD). The significant differences among means were 
analyzed using the Analysis of Variance (ANOVA). Where the computed F- value $=$ Table F- value, there is significant difference among perfekthion levels. But if the computed F- value $<$ table F-value, there is no significant difference among perfekthion levels in which case the analytical method by Scheffe (1957) was used. Correlation was carried out on the physicochemical and biological parameters (mortality). Dose-response (Mortality) data was analysed using probit method for indices of toxicity to calculate the $50 \%$ lethal concentration $\left(\mathrm{LC}_{50}\right)$ after Finney (1971). The median lethal time $\left(\mathrm{MLT}_{50}\right)$ was obtained by plotting a graph of percent death against time of death. Safe concentrations were calculated from 96-h $\mathrm{LC}_{50}$ using the 0.1 application factor (EIFAC, 1983).

\section{RESULTS}

Physical and chemical parameters

The physical and chemical parameter values obtained for $S$. melanotheron are presented in Table 1. A pH range of 6.96-7.45 was obtained from the test tanks. This varied slightly from the control with mean value of $7.45 \pm 0.41$. The highest value was seen in concentration level $0.7 \mathrm{mg} / 1$ with a mean of $7.41 \pm 0.37$ and the lowest in concentration level $11.2 \mathrm{mg} / \mathrm{l}$ with the highest concentration with a mean of $6.96 \pm 0.11$. Throughout the test period, the dissolved oxygen fluctuated significantly within a range of $2.9-$ $5.4 \mathrm{mg} / 1$ with the highest values at the first and third days and in the control with a mean of $4.73 \pm$ 0.73 . Variations in temperature occurred with the highest value as $26.33 \pm 0.98$ in the control chamber and lowest value $26.10 \pm 0.84$ in concentration level $0.7 \mathrm{mg} / \mathrm{l}$. There was variation in temperature. The highest value $26.38 \pm 1.04$ was in $5.6 \mathrm{mg} / \mathrm{l}$. The lowest value $(26.10 \pm 0.84)$ was obtained in concentration level $0.7 \mathrm{mg} / 1$. There was similar variation in total alkalinity and total hardness. The highest value for TA was $55.98 \pm$ 3.91 and occurred in concentration level $2.8 \mathrm{mg} / 1$. The lowest value of $51.93 \pm 1.44$ was in concentration level $11.2 \mathrm{mg} / \mathrm{l}$. Very slight variations was obtained for salinity. The lowest value was 6 . $75 \pm 2.22 \mathrm{ppt}$ and was obtained in concentration level $0.7 \mathrm{mg} / 1$ and the highest value $(7.0 \pm 2.16 \mathrm{ppt})$ was observed in concentration level $1.4 \mathrm{mg} / \mathrm{l}$. The lowest mean value for total hardness was 1434.93(control) while, the highest mean value $(1748 \pm 76.33)$ was observed in concentration level $11.2 \mathrm{mg} / \mathrm{l}$.

Table 1. Physical and chemical parameters of the test media

\begin{tabular}{lllllll}
\hline & $\mathrm{Ph}$ & $\mathrm{DO}(\mathrm{mg} / \mathrm{l})$ & $\mathrm{Temp}\left({ }^{0} \mathrm{C}\right)$ & $\mathrm{TA}(\mathrm{mg} / \mathrm{l})$ & $\mathrm{TH}(\mathrm{mg} / \mathrm{l})$ & Salinity $(\mathrm{ppt})$ \\
\hline Control & $7.45 \pm 0.41$ & $4.73 \pm 0.73$ & $26.25 \pm 1.04$ & $55.90 \pm 4.22$ & $1434.93 \pm 45.30$ & $6.75 \pm 2.36$ \\
$0.7 \mathrm{mg} / 1$ & $7.41 \pm 0.37$ & $4.38 \pm 1.07$ & $26.10 \pm 0.84$ & $55.30 \pm 2.73$ & $1481.28 \pm 55.30$ & $6.75 \pm 2.22$ \\
$1.4 \mathrm{mg} / 1$ & $7.35 \pm 0.35$ & $4.00 \pm 0.83$ & $26.20 \pm 0.85$ & $54.83 \pm 3.83$ & $1553.93 \pm 52.55$ & $7.00 \pm 2.16$ \\
$2.8 \mathrm{mg} / 1$ & $7.39 \pm 0.35$ & $3.85 \pm 0.89$ & $26.33 \pm 0.98$ & $55.98 \pm 3.91$ & $1636.23 \pm 56.30$ & $6.75 \pm 2.36$ \\
$5.6 \mathrm{mg} / 1$ & $7.32 \pm 0.29$ & $4.25 \pm 0.93$ & $26.33 \pm 0.85$ & $53.73 \pm 4.04$ & $1712.60 \pm 74.98$ & $7.00 \pm 2.45$ \\
\hline $11.2 \mathrm{mg} / 1$ & $6.96 \pm 0.11$ & $4.40 \pm 0.99$ & $26.13 \pm 0.63$ & $51.93 \pm 1.44$ & $1748.70 \pm 76.33$ & $7.00 \pm 2.45$ \\
\hline
\end{tabular}

\section{Mortality}

Figure 1 shows the percentage mortality of Sarotherodon melanotheron exposed to various levels of perfekthion. The tendency was an increase in mortality but this was not consistent as mortality halted and was even lower at the middle concentration level of $2.8 \mathrm{mg} / 1$. This mortality rate was lower than the relative lower concentration levels of $0.7 \mathrm{mg} / 1$ and $1.4 \mathrm{mg} / 1$. However, mortality increased significantly with increase in concentration level and exposure time. Ten percent mortality was observed in the control $(0 \mathrm{mg} / 1), 3 \%$ mortality was recorded after 12 hours and $7 \%$ at the end of 36 hours. At the lowest concentration of $0.7 \mathrm{mg} / 1,27 \%$ mortality occurred after 12 hours and $30 \%$ mortality occurred after 24 hours. At the 48 th hour, the rate increased to $37 \%, 47 \%$ after 72 hours and afterwards no further death was observed till the end of the experiment. At $1.4 \mathrm{mg} / 1,20 \%$ mortality occurred after 12 hours, this increased to
$37 \%$ after 24 hours, $43 \%$ after 36 hours, $53 \%$ after 60 hours, $63 \%$ after 72 hours, $73 \%$ after 84 and $77 \%$ after 96 hours. Mortalities occurred in concentration level $2.8 \mathrm{mg} / 1$ at the rate of $7 \%$ after 12 hours, $13 \%$ after 24 hours, and $20 \%$ after 36 hours and $7 \%$ mortality after 48 hours. This increased to $43 \%$ after 60 hours and remained at $47 \%$ mortality from the $72^{\text {nd }}$ hour till the end of experiment. At concentration level $5.6 \mathrm{mg} / \mathrm{l}$, mortality was $43 \%$ within 12 hours, this increased to $47 \%$ after 24 hours and $50 \%$ at the end of the $36^{\text {th }}$ hour. No further mortality occurred till the $60^{\text {th }}$ hour when $60 \%$ was observed. This continued to $63 \%$ after 84 hours and $67 \%$ at the end of the toxicity test. At concentration level $11.2 \mathrm{mg} / 1$ mortality, at the end of 96 hours, mortality was $97 \%$. At the $12^{\text {th }}$ hour, $43 \%$ was observed dead. It increased to $70 \%$ at the $48^{\text {th }}$ hour and $97 \%$ at the 96 hour. There was significant effect of perfekthion on $S$. melanotheron fingerlings $(\mathrm{P}<0.05)$ although there was delayed mortality at concentration 2.8mg/l. (Table 2). 


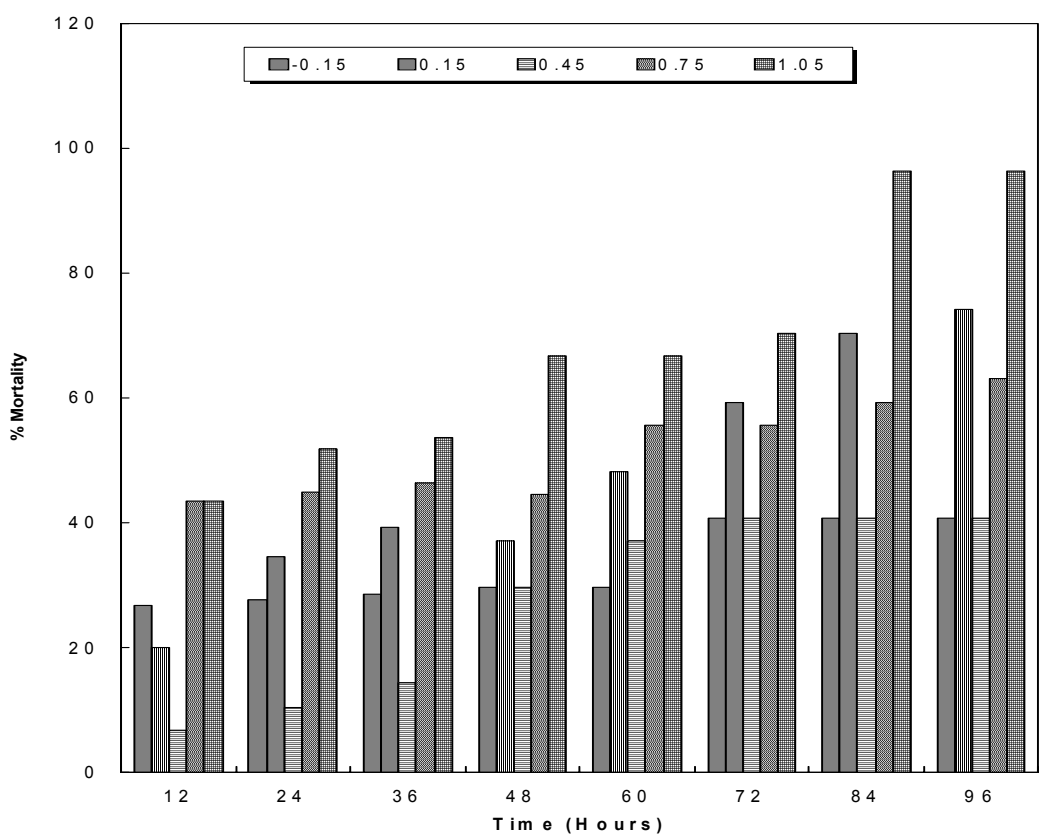

Fig. 1: Percent mortality of Sarotherodon melanotheron fingerlings at the various concentrations of perfkthion

Table 2. Analysis of variance for $\mathrm{S}$ melanotheron exposed to various levels of perfekthion.

\begin{tabular}{lllllll}
\hline $\begin{array}{l}\text { Anova: Single Factor } \\
\text { SUMMARY }\end{array}$ & & & & & & \\
Groups & Count & Sum & Average & Variance & & \\
Conc & 5 & 21.7 & 4.34 & 18.228 & & \\
Mortality & 5 & 335 & 67 & 450 & & \\
ANOVA & & & & & P-value & F crit \\
Source of Variation & SS & Df & MS & $F$ & 0.000193 & $\mathbf{5 . 3 1 7 7}$ \\
Between Groups & 9815.689 & 1 & 9815.689 & $* * \mathbf{4 1 . 9 2 7 0}$ & & \\
Within Groups & 1872.912 & 8 & 234.114 & & & \\
Total & 11688.6 & 9 & & & & \\
\hline
\end{tabular}

Table 3 Correlation of physical and chemical parameters and percentage mortality.

\begin{tabular}{llllllll}
\multicolumn{7}{c}{ Table 3 Correlation of phsical and chemical parameters and percentage } & mortality. \\
\hline PH & $\mathbf{p H}$ & $\mathbf{D O}$ & Temp & TA & TH & Salinity & Mortality \\
DO & 1 & & & & & & \\
Temp & -0.06036 & 1 & & & & & \\
TA & 0.35159 & -0.31224 & 1 & & & \\
TH & 0.937953 & -0.12557 & 0.252022 & 1 & & \\
Salinity & -0.75237 & -0.3741 & 0.257187 & -0.77141 & 1 & \\
Mortality & -0.6369 & -0.17594 & 0.041922 & -0.78822 & 0.670528 & 1 & \\
& -0.76814 & -0.44789 & -0.22877 & -0.79766 & 0.779478 & 0.806221 & 1 \\
Control & Control & $\mathbf{A}$ & $\mathbf{B}$ & $\mathbf{C}$ & $\mathbf{D}$ & $\mathbf{E}$ & \\
A & 1 & & & & & & \\
B & 0.999477 & 1 & & & & & \\
C & 0.998698 & 0.999825 & 1 & & & \\
D & 0.999527 & 0.999995 & 0.999791 & 1 & & \\
E & 0.999111 & 0.999943 & 0.999951 & 0.999934 & 1 & \\
\hline
\end{tabular}

$\mathrm{LC}_{50}$ was not reached within 12 hours. As exposure time increased, $\mathrm{LC}_{50}$ reduced. The median Lethal Time $\left(\mathrm{LT}_{50}\right)$ values of the concentration levels, $1.4 \mathrm{mg} / 1,2.8 \mathrm{mg} / 1,5.6 \mathrm{mg} / 1$ and $11.2 \mathrm{mg} / 1$ was 57.85 hours, 91.52 hours, 48.35 hours and 27.61 hours respectively. $\mathrm{LT}_{50}$ increased with decrease in concentration level with the least value (27.61) at the highest concentration of $11.2 \mathrm{mg} / 1$ as compared to 57.85 hours at $1.4 \mathrm{mg} / \mathrm{l}$. The safe concentration of perfekthion organophosphate insecticide was $0.119 \mathrm{mg} / \mathrm{l}$. The correlations between all physical, chemical and biological parameters used are presented in Table 3. Generally, the relationship revealed positive, negative, strong and/or weak correlations. There were strong positive correlations between concentrations levels $(\mathrm{r}=$ $0.9982-\mathrm{r}=0.9999)$. The correlation of $\mathrm{pH}$ with total alkalinity was $r=0.9379$, total hardness with 
salinity $(r=0.6705)$. Weak positive correlation occurred between $\mathrm{pH}$ and temperature $(\mathrm{r}=0.3516)$, temperature with TA and $\mathrm{TH}(\mathrm{r}=0.2572$ and $\mathrm{r}=$ $0.0419)$. Negative correlations occurred for $\mathrm{pH}$ and DO $(\mathrm{r}=-0.0604), \mathrm{pH}$ and $\mathrm{TH}(\mathrm{r}=-0.7524), \mathrm{pH}$ and salinity $(\mathrm{r}=-0.6369)$ and Do with salinity $(\mathrm{r}=$ 0.1759 ). In relation to biological parameters (mortality), strong positive correlations existed between mortality and $\mathrm{TH}$, salinity $(\mathrm{r}=0.7795, \mathrm{r}=$ 0.8062). Negative correlations existed between mortality and $\mathrm{pH}$, TA $(\mathrm{r}=-0.7681, \mathrm{r}=-0.7977)$ and in mortality with DO and temperature $(\mathrm{r}=-0.4479$ and $\mathrm{r}=-0.2288$ ) respectively.

\section{DISCUSSION}

The results from the study showed that water quality was within recommended limits. Variations that occurred within the parameters were within the tolerable ranges throughout the acclimation, range finding and the actual bioassay test. Temperature varied at $\pm 1^{\circ} \mathrm{c}$, which is within the recommended ranges of $\pm 1-3^{0} \mathrm{C}$ (FAO, 1973). The recommended limit of dissolved oxygen (DO) for fish is $5 \mathrm{mg} / 1$ (FAO, 1973), but conversely, Alabaster and Lloyd (1980) recommended a range of $2 \mathrm{mg} / 1-7 \mathrm{mg} / \mathrm{l}$. The range of DO was within the tolerable limits (Campbell, 1987). FEPA (1991) recommended 6 9 unit range for $\mathrm{pH}$. Bennet (1973) stipulated a range of $5.5-10$ for tropical fishes. Total alkalinity showed a positive index of potential productivity for the waters at 51.93 - 55.90 for brackish water species (Umeham, 1989; U.S. EPA, 1986). The high value of total hardness obtained could be attributed to the total solids and nutrient enrichment of the estuarine ecosystem (Wooton, 1992). Dissolved oxygen levels reduced at day and this could be attributed to the respiratory activities of the fish. The values of the water quality of the test waters indicated that perfekthion pesticide did not adversely affect the water quality. Mortality recorded was probably due to direct effect of Perfekthion on the fish. Mortality rates increased progressively but delayed mortality was observed. This indicated that the pesticide could induce a toxicity trend that could delay mortality. This trend was also observed by, Tjeerdema (2005) in his work on Chinook salmon smolts exposed to water Accommodating Fraction of crude. A mean survival of $0.58 \%$ at a concentration of $0.39 \mathrm{~g} / 1$ and 0.835 at a relatively higher concentration of $0.78 \mathrm{~g} / 1$ was reported. Nevertheless, towards the highest concentration levels, mortality rates increased with the peak at the highest concentration levels. This was in conformity with the findings of several other authors (Wade et al., 2002; Omoregie et al., 1990; Annune and Ajike, 1999; Aguigwo, 2002; Okoli-Annuobi et al., 2002) and this followed the rule in classical toxicology. The frequency of toxic effects of many toxic substance declines with decline in dosage (Feliciano, 1980). Although, 10\% mortality was recorded, not more than $10 \%$ mortality is pemitted in toxicity tests (FAO, 1973). The $\mathrm{LC}_{50}$ values obtained for $S$. melanotheron exposed to perfekthion organophosphate insecticide was relatively high compared to other types of pesticides and this could be attributed to the fact that perfekthion is not very toxic. Dimethoate generally, has a short half-life of 4-7 days. This may explain why percentage mortality ratio per 12 hours reduced after $24-48$ hours (Hassal, 1990).

Many authors have carried out several toxicity tests using other pesticides. Ita (1993) documented 96-h $\mathrm{LC}_{50}$ of lindane for different species. He reported $0.016,0.08,0.27$ and $0.002 \mathrm{mg} / \mathrm{l}$ for lindane exposed Lepomis macrochirus (Bluegill), Salmon, Carassius auratus (Gold fish) and Salmo gairdneri (Rainbow trout) respectively. These values are low compared to dimethoate (Perfekthion). Melnikov et al. (1977), reported a 96-h $\mathrm{LC}_{50}$ of dimethoate in $\mathrm{mg} / \mathrm{l}$ for rainbow trout as 8.5 and EXTONET (1996) reported 6.2 for the same rainbow trout and 6.0 for blue gill. Rainbow trout and blue gill were exposed to some types of carbamate pesticide (Carbamates have the same mode of action with organophosphates, e.g. perfekthion) and lower values were reported. Yoshida and Nishiuchi (1972) and Nishiuchi (1974) reported values of $0.05 \mathrm{mg} / 1$ and $0.56 \mathrm{mg} / 1$ of aldicarb carbamate and $0.85 \mathrm{mg} / \mathrm{l}$ and $0.17 \mathrm{mg} / 1$ of benomyl for the respective species. These values compared to perfekthion showed that perfekthion is safer for use as per safe concentrations in nature. $S$. melanotheron fingerlings recovered after the experiment. This could be attributed firstly, to the dephosphorylation process that set in as treatment ceased (Reiner, 1971). Gallo and Lawryk (1991) confirmed this in dimethoate treated cows at $30 \mathrm{mg} / \mathrm{kg}$. After treatment, levels of $0.02 \mathrm{ppm}$ was detected in the blood and milk and this level reduced to $0.01 \mathrm{ppm}$ after 9 hours which confirmed that this pesticide could be excreted from the system.

Secondly, this property could be attributed to the fact that perfekthion is non-persistent and easily hydrolyzed (Howard, 1991; Wauchope et al., 1992). This non-persistent characteristic gives perfekthion and other organophosphates a better stand for usage than the organochlorines and inorganic pesticides that have high cumulative tendencies (Odiete, 1999; Atuma, et al., 1985). Rates of $11-121 \mathrm{ppm}$ of arsenical inorganic pesticide (Alhifi, 2006) and factors of 41 - 1298 of aroclor organochloride pesticide (Neff and Gaim, 1977) have been reported both in animal tissues and sediments. The moderate toxicity of dimethoate (Perfekthion) has been established in the U. S EPA toxicity class II (EXTONET, 1996) and $\mathrm{Du}$ Bois and Geiling (1959) grouped it as moderately toxic $(200 \mathrm{mg} / \mathrm{kg})$ in an empirical scale of assessment of toxicity level. This compared with results from this study. Anees (1975) reported a 
$\mathrm{TL}_{\mathrm{m}}$ of $20.5 \mathrm{mg} / 1$ for Channa punctatus, Dikshith and Raizada (1981) and Dikshith (1986) reported $47 \mathrm{mg} / \mathrm{l}$ (96-h) for the same specie and Verma et al. (1978) reported a $\mathrm{TL}_{\mathrm{m}}$ of $4.5 \mathrm{mg} / 1$ for Channa gachua. Zebra fish exposed to dimethoate (Cygon) gave a $\mathrm{TL}_{\mathrm{m}}(72-\mathrm{h})$ of $259 \mathrm{mg} / \mathrm{l}$ (Roales and Permutter, 1974). Richgrow (2005) documented 40-60mg/l in a 96-h exposure for mosquito fish to rogor-dimethoate. Conversely, Annune and Ajike, (1999) reported a very low $\mathrm{LC}_{50}$ of $0.018 \mathrm{mg} / \mathrm{l}$ for $O$. niloticus juveniles exposed to dimethoate (Regor).

The mortalities observed in this study could be attributed to respiratory stress and asphyxiation as the gills were badly damaged and eroded. Gill hemorrhages were observed at death. The gill tissues (epithelia and filaments) were ruptured, lifted and eroded. This could be the reason why the fish died with mouths open as they gasped for air due to gas exchange failure at the gill surfaces. This was confirmed by, Pascoe and Mattey (1977) after a work on cadmium toxicity effect on stickleback (Gasterosteus aculeatus L.). The result showed that at $100 \mathrm{mg} / 1$, death occurred presumably by the direct gill damage and Okoli-Anunobi et al. (2002) reported cases of ruptured and hemorrhaged gills and opercula flaps in $O$. niloticus exposed to detergent. They concluded that it resulted in severe respiratory stress and asphyxiation. Several other authors worked with various types of toxicants and concluded that the gill is a good pollution indicator parameter in environmental toxicity monitoring. The histological examination of the gills of $O$ niloticus exposed to cassava effluent revealed oedema and telangiectasis of the gill lamellae and gill hyperplasia at $0.46 \mathrm{mg} / 1$ (Wade et al; 2002) as well as $O$. niloticus exposed to actellic $25 \mathrm{EC}$ (Omoregie and ufodike, 1999). Aguigwo (2002) reported respiratory distress and death of all fish exposed to 4 and $5 \mathrm{mg} / 1$ concentration of cymbus pesticide. Same was reported by Tortorelli et al. (1990) for catfish fry (Plecostomus commersoni) exposed to Paraquat herbicide. Several other authors reported gill epithelial cell damage in paraquat exposed fish (Tortorelli et al., 1990), lamellar disarray and epithelial swelling in brown trout exposed to lindane (Drewett and Abel, 1983). Also, necrotic damage in gill epithelium in common carp exposed to copper sulphate pesticide (Asztalos and Newcsok, 1985), gill haemorrhage and accumulated mucus on $O$. niloticus gill exposed to rogor (Annune and Ajike, 1999) and gill filament erosion and loss of cell membrane of Channa gachua, exposed at $6.2 \mathrm{mg} / 1$ of dimethoate (Dalela et al., 1979).

\section{REFERENCES}

Aguigwo, J.N. (2002) The toxic effect of cymbush pesticide on growth and survival of African catfish, Clarias gariepinus (Burchell). Journal of Aguatic sciences, 6:13-17.
Alabaster, J.S. and Lloyd, R. (1980) Water quality criteria for fresh water fish. Butterworth and Co.Ltd, London:pp.12-260.

Alhifi, M. (2006) Pesticides: the necessary evil. Issue: (942) volume 14.

Anderson, I. W; Nett, J. M; Cox, B. A; Tatem, H. E and Hightower, G M (1974). The effect of oil on estuarine animals: Toxicity, uptake and deputation and respiration: In: Pollution and physiology of marine organisms (eds). F. J Vernberg and EIB Vernberg. Academic press, New York. 285 - 310.

Anees, M.A. (1975) Acute toxicity of four organophosphorous insecticides for a freshwater teleost, Channa punctatus. Pak. J. 2001, 7(2): 135-141.

Annune, P.A. and Ajike, S. U. (1999) Acute toxicity and gill morphology of Oreochromis niloticus (Trewavas) exposed to Rogor. Journal of Aquatic Sciences, 14:1-4

APHA (American Public Health Association), American Water Works Association and Water Pollution Control Federation (1985) Standard methods of examination of water and wastewater $\left(16^{\text {th }}\right.$ ed.) APHA New York: PP.1193.

Atuma , S.S., Okor, D.I. and Adeniyi, H.A. (1985) Persistence of pesticides in Kainji environment, Nigeria. Journal of Applied science, 5 (1): 97-105.

Asztalos, B and Nemcsok, J. (1985) Effect of pesticides on the LDH activity and isoenzyme pattern of carp (cyprinus carpio, L.). Comparative Biochemistry physiology :82c(1) :217-219.

Bennet, G.N. (1983) Winter kill of fishes in an Illinois lake. Lake management reports Illinois biology notes. 19:1-9.

Campbell, D. (1978) A review of the culture of Sarotherodon melanotheron in West Africa. FAO corporate Document Repository. Project $\mathrm{RAF} / 82 / 009$.

Davids, C.B.D. (1999) Haematological parameters of T. guinensis and S.melanotheron exposed to industrial effluents in Okrika creeks and environments. M.Sc thesis, Rivers State Univ. of Science and Technology, Port Harcourt, Rivers State. pp.90.

Dalela, R.C., Bhatnagar, M.C., Tyagi, A.K. and Verma, S.R. (1979) Histological damage to 
gills in Channa gachua after acute and subacute exposures to endosulfan and rogor. Mikroskopie (Vienna). 35: $301-307$

Dikshith, T.S.S. and Raizada, R.B. (1981) Toxicity evaluation of dimethoate technical in fish (Report to Shaw Wallace \& C.O., India).

Dikshith, T.S.S. (1986) Pesticides. In: Toxicology of pesticides in animals, Boca Raton, Florida, CRC. Press, vol. 1 chapter 2

Drewett, N. and Abel, P.D. (1983) Pathology of lindane poisoning and of hypoxia in the brown trout, Salmo trutta, L. Journal of fish biology, 23: $273-384$.

Du Bois, K.P. and Geiling, E.M.K. (1950) Textbook of toxicology. Oxford Univ. Press, Oxford.

EIFAC. (1983) European Inland Fisheries Advisory Commission. Revised report on fish toxicity testing procedures. EIFAC Technical paper no. 24 Revision 1: 37.

EXTONET (1996) Extension Toxicology Network. Pesticide information profiles: Dimethoate. Oregon State University.

FAO. (1973) Manual of methods in aquatic environment research: Part 10- short-term static bioassays. FAO Fishers Technical Paper, 247.

Feliciano, D.V. (1980) Toxics - truth and consequences. Monitor. Journal WPCF, Vol.52, No. 7: 1856.

FEPA (1991) Guidelines and standards for environmental pollution control in Nigeria. Federal Environmental Protection Agency, Nigeria.

Finney, D.I. (1971) Probit analysis $3^{\text {rd }}$ ed. Cambridge University Press. London: pp.333.

Foster, M; Charlse, A C and Neushul, M (1971). The Santa Barbara oil spill. Part 1- Intial quantities and distribution of polluted crude. Pollut. 2. 79-114.

Gallo, M.A. and Lawryk, N.J. (1991) Organic phosphorous pesticides. In: Handbook of Pesticide Toxicology. Hayes, W. J. Jr. and Laws, E.R.Jr. (Eds). Academic press, New York: pp.5- 13.

Gourene, G and Teugel, G (1991). Clupeidae in fresh and brakish water water fishes of West Africa. Vol. 1. Loveque c, Paugy D and Teugel G(eds). Fauna Tropical xxvii. 89-111.
Hanazota, T and Kasai, F (1995). Effects of the organophosphorus insecticide fenthion and phyto and zooplanktion communities in experimental ponds. Environmental pollution. 88: 253-293

Hassal, K.A. (1990) The biochemistry and uses of pesticides. Macmillan press Ltd, Hong Kong: pp.7- 124.

Howard, P.H. (1991) Handbook of Environmental Fate and Exposure Data for Organic Chemicals: Pesticides. Lewis publishers, Chelsea, MI.vol. 3:5-13.

Lee, D.S., Gilbert, C.R., Hocutt, C H., Jerkins, R.E., Mc Allister, D.E. and Stanffer, J.R.Jr. (1980) Atlas of North American freshwater fishes. North carolina State Museum of Natural History, Special Publication Biological Survey. pp.773.

Loveque, C; Pyugy, O and Teugels, G. G (1991). The fresh and brakish water fishes of West Africa, Musee Royale De. 1 Africque Centrale, Tervurem, Belgique. Edition De 1. ORESTO. 38pp.

Melnikov, N. N; Volkov, A. I. and Korotkova, O. A. (1977) Pesticides and the environment. Khimiya publishers, Moscow : 240.

Neff, J. M. and Giam, C. S. (1977). Effect of Aroclor 1016 and Halowax 1099 on Juvenile horseshoe crabs Limulus polyphemus. In: Physiological Responses of Marine Biota to Pollutants. Academic Press, New York: pp. 21 -35 .

Nishiuchi, Y. (1974) Toxicity of pesticides formulation to some fresh water organisms XXIII. Aquaculture, $22: 16-18$.

Odiete, W. O (1999) Environmental Physiology of animals and pollution. Diversified Resources Ltd, Lagos: pp. 193 - 246.

Okoli - Anunobi, C. A. I. N., Ufodike, E. B. C. and Chude, L. A. (2002) Lethal effects of the detergent, Elephant Blue on the Nile tilapia, Oreochromis niloticus (L), Journal of Aquatic Sciences, 17(2):95 - 97.

Omoregie, E., Ufodike, E. B. C. and Keke, I. R. (1990) Tissue Chemistry of $O$. niloticus exposure to sublethal concentrations of gammalin 20 and Actellic 25EC. Journal of Aquatic Sciences, 5: 33 - 36.

Omoregie, E. and Ufodike, E. B. C. (1999) Effect of crude oil exposure on growth, feed 
utilization and food reserves of the Nile tilapia, O. niloticus (Trewavas). Acta Hydrobiologica, 41: $259-268$.

Pascoe, D. and Mattey, D. L. (1977) Studies on the toxicity of cadmium to the three-spined stickleback, Gasterosteus aculeatus (L). J. fish Biol. 11, $207-215$.

Reiner, E. (1971) Spontaneous reactivation of phosphorylated and carbamylated cholinesterases. Bull. W. H. O., 44: $109-112$.

Richgro W (2005). Material Safety Data Sheet Rogor insecticide. Richgro Garden Products. Hazardous according to criteria of NOHSC, Australia.

Scheffe D (1957).An introduction to analysis to variance, John Wiley, New York. 225p.

Sprague, J. B. (1970) Measurement of Pollutant toxicity to fish: II utilizing and applying bioassay results. Water Research. 4: 3-32. Stedman's medical dictionaries (2005)

Tjeerdema, R. S. (2005) Acute and chronic effects of crude and dispersed oil on Chinook Salmon Smolts (Oncorhynchus tshawytscha). NOAA/UNH coastal Response Research Center, Project no. $04-843$, California.

Tortorelli, M. C., Hernandez, D. A. Vazquez, G. R. and Salibian, A. (1990) Effects of Paraquat on mortality and Cardiorespiratory function of catfish fry, Plecostomus Commersoni. Archives of Environmental contamination and Toxicology, vol.19 (4):523 - 529.

Trewavas, E. (1983) Tilapine fishes of the genera, Sarotherodon, Oreochromis and Danakilia. British museum of natural history, Publ. Num. 878. Comstock publishing associates, Ithaca, New York: pp. 583.

Ufodike, E. B. C and Madu, C. T. (1986) Effects of methyltestosterone on food utilization and growth of Sarotherodon niloticus fry. Bulletin of the Japanese Society of Scientific Fisheres, 12 : $1991-1922$.

Ufodike, E. B. C. and Wada, I. R. K. (1991) Food and feeding habits of Sarotherodon nilotica
(Perciformis: Cichlidae) fry in Rock water fish farm, Jos, Nigeria. Revista de Biologia Tropical 39: $189-192$

Ufodike, E. B. C. and Omoregie, E. (1990) Acute toxicity of gammalin 20 and actellic $25 \mathrm{EC}$ to O. niloticus niloticus. Acta Hydrobiologica 32: $447-455$.

Umeham, S. N. (1989) Some aspects of the physico-chemical limmology of Lake Chad (Southern Sector). Journal of Aquatic Sciences 4: $21-26$.

U. S. EPA. (1986) U. S. Environmental Protection Agency. Pesticide Fact Sheet Number 100: Azinphos-methyl. Office of pesticides and toxic substances, Washington, D. C. pp. 5 18.

Verma, S. R., Bhatnagar, M. C. and Dalela, R. C. (1978) Biocides in relation to water pollution. II. Bioassay studies of a few biocides to a fresh-water fish, Channa gachua. Acta hydrochim. Hydrobiol., 6(2): 137 - 144.

Wade, J. W. Omoregie, E. and Ezenwaka, I. (2002) Toxicity of Cassava (Manihot esculenta (Crantz) effluent on the Nile tilapia ( $O$. niloticus, (L) under laboratory conditions. Journal of Aquatic Sciences 17 (2): 89 - 94.

Wauchope, R. D., Buttler, T. M. Hornsby, A. G. Augustijn-Beckers, P. W. M. and Burt, J. P. (1992) SCS/ARS/CES pesticide properties database for environmental decision making. Rev. Eviron. Contam. Toxicol. 123; $1-157$, pp. $5-20$.

Whitehead, P. J. P (1984). Family Clupeidae. Daget J. Gosse, J P. Thys. Van. Den. Audennered, D. F. S(eds). Checklist of the freshwater fishes of Africa. ORSTOM 1. 1120.

Wootton, R. J. (1992) Fish ecology. Blackie and Son Limited, Glassglow: pp. 215.

Yoshida, K. and Nishiuchi, Y. (1972) Toxicity of pesticides to some water organisms. Bull Agric. Chem. Inspect. Stn (Japan), 12; 122 128. 